\title{
The Ethnolinguistic Vitality of the Dumagat Communities in Three Philippine Provinces
}

\author{
$1^{\text {st }}$ Romualdo A. Mabuan ${ }^{1 *}$ \\ \{romualdo.mabuan@lpu.edu.ph ${ }^{1}$ \} \\ Lyceum of the Philippines (LPU), Manila Campus, Muralla St, Intramuros, Manila, 1002 Metro \\ Manila, Philippines ${ }^{1}$
}

\begin{abstract}
This paper presents the findings of sociolinguistic research conducted between 2013 and 2015 among the Dumagat indigenous communities in Aurora, Bulacan, and Quezon Province. The primary goal of the study is to investigate the factors that account for the ethnolinguistic vitality of these communities. Employing qualitative techniques, data were gathered using interviews, participant observation, and focus group discussions (FGDs). Interview data were analysed using the nine criteria of language vitality and endangerment outlined in the UNESCO Expert Meeting in March, 2003 and were triangulated by the data gathered from participant observation and FGDs. Results reveal varying levels of language vitality among these Dumagat communities as influenced by factors that include social factors (social stigma, exogamy or external marriage, and migration patterns), institutional factors (governmental policies, support, and reforms), and linguistic factors (language contact, linguistic attitude, and language use). These findings situate these indigenous communities in the continuum of language reinvigoration and revitalization and implicate inter-level agencies to design feasible framework to document, cultivate, and protect this indigenous language for future generations of these IP communities.
\end{abstract}

Keywords: Ethnolinguistic Vitality; Language Vitality; Ethnolinguistic Vitality of Dumagat; Language Vitality of Dumagat Communities.

\section{Introduction}

Today, around 30 of over 150 Proto-Malayo-Polynesian (PMP) languages are spoken by negrito populations in the Philippines [1]. Many of these are severely endangered languages or have become extinct within recent historic times [2]. Apparently, when look at Reid's [3], Revised subgrouping of Cordilleran languages, notice that he did not specifically account for this variety; thus, the closest subgroup can identify it is the DumagatUmiray which is spoken by the negrito groups in the north eastern Luzon under the Northern Cordilleran language subgroup.

The Dumaget language is one of the five languages in the North Eastern Luzon Group of Northern Cordilleran languages [4]. The other languages include Palanan Dumagat, Paranan, Casiguran Dumagat and East Cagayan Dumagat. Genetically related, these languages may be morphologically and phonologically different from one another, but they are semantically related. BayaniAzcarraga states (Dumagat leader): "Magkakaiba man ang ibangsalita at pagbikasnamin, nagkakaintindihan pa rin kami dahil halos pareholangnaman ang 
aminglenggwahe."(Some of our words and pronunciation may be different, but we still understand one another because our language is almost similar.)

The traditional economy in Sitio Pinag-anakan, Barangay Cabog, and Sitio Masla has been, and still remains, hunter-gathering and swidden ('kaingin') farming, and this is reflected on their practices, though some may take on seasonal jobs being fishermen, cottage industry and construction workers. Some do not have any particular jobs at all and may take on any casual jobs available.

The traditional religion of the Dumagats in these areas is the consecration of their God "Makedepat" and the observance was high. However, it has gradually changed with the introduction of Christianity in their communities by some religious groups during 1980s and 1990s. Nowadays, they identify themselves as Christians, Iglesia Ni Cristo, Mennonites and Seventh Day Adventist, while some remain to embrace their traditional belief.

Pinag-anakan Elementary School is the only public elementary school located in Sitio Pinag-anakan, Barangay Kabayunan, Norzagaray, Bulacan. It offers Grades 1 to 6 and is under the administration of the Department of Education. Currently there are two teachers conducting multi-grade classes with 46 Dumagat schoolchildren, who live within the Angat Dam watershed areas. Barangay Cabog in Dingalan, Aurora has one public elementary school, Cabog Elementary School, and one public high school, Cabog High School, which are just a stone's throw from the Dumagat community. Both Dumagat and Tagalog schoolchildren attend classes.

Currently, there are two public elementary schools in Barangay Sablang, General Nakar, Quezon: Sablang Elementary School, which is a mainstream school, and KatutubongPaaralang Jose P. Laurel (KPJPL), a school built primarily for the Dumagat schoolchildren, and is donated by the PUGAHAN Project (Pamana'yUgatin, Hasain at Arugain) with the collaboration of Lyceum of the Philippines University (LPU), National Commission on Indigenous Peoples (NCIP), and AusAID (Australian Agency for International Development). There is one teacher handling multi-grade classes from Grades 1 to 3, and there is a community teacher conducting Dumaget mother tongue classes for an hour every day.

Like any political units in the Philippines, Barangay Kabayuna, Barangay Cabog, and Barangay Sablang are governed by their respective barangay captains and barangay councillors who are duly elected during the local elections. These barangay officials are responsible for maintaining peace and order in their communities as well as implementing government projects. As mandated by the Philippine Constitution, all community members who are eligible voters can participate in the election of these local officials.

However, aside from the barangay officials, the Dumagats have another political structure, the Tribal Council, which is headed by their Chieftain and his council members. This political sub-unit operates within the context of barangay, and its main duty is to oversee its own people. In short, the Barangay and the Tribal Council work hand-in-hand to maintain a peaceful and orderly community for the benefit of all.

This study aims to investigate the ethnolinguistic vitality of some selected Dumagat communities (Sitio Cabog, Barangay Matawe, Dingalan, Aurora; Sitio Pinag-anakan, Barangay Kabayunan, Angat,Bulacan; and Sitio Masla, Barangay Sablang, General Nakar, Quezon) along the Sierra Mountain range. Also, identify the the factors contributing to the ethnolinguistic vitality situation of the Dumaget language in these communities. 


\section{Methodology}

\section{The Concept of Ethnolinguistic Vitality}

In order to place social identity (and other social psychological) processes underlying ethnolinguistic behaviour in their appropriate sociostructural contexts, Giles, Bourhis, and Harwood [5] introduced the notion of Ethnolinguistic Vitality. It was defined as "that which makes a group likely to behave as a distinctive and active collective entity in intergroup situations". Giles et al. [5] proposed that group's strengths and weaknesses on dimensions of institutional support and control as well its social status and demographic strength may be assessed "objectively" to provide a rough overall classification of ethnolinguistic groups as having low, medium or high vitality. It was argued that the more vitality an ethnolinguistic group has the more likely it would be to survive as a distinctive linguistic collectivity in intergroup settings. Conversely, groups that have little or no group vitality were expected to assimilate linguistically or cease to exist as distinctive groups.

John Edwards [6], working under the framework of Ethnolinguistic Vitality, constructed his 'typology of language endangerment' which he specifically designed to research minority language situations. Edwards set eleven areas of factors that can influence a group's ethnolinguistic vitality at three different levels. The eleven areas are demography, sociology, linguistics, psychology, history, politics (including law and government), geography, education, religion, economics, and the media. The three levels are 'speaker', which does not mean the individual speaker but the minority speech community; then 'language', which signifies the relationship between the minority language as an object and the area of influence in question; and finally 'setting', which situates the minority community within the majority community.

Grenoble and Whaley [7] present and refine a scheme laid out by Edwards [6], which seeks to give an overview of all those factors that have a bearing on ethnolinguistic vitality. The factors in their refined scheme are demography, sociology, linguistics, psychology, history, politics, geography, education, religion, economics, technology, and literacy. Each of these factors can be analysed on the micro-level (that is, with respect to the language itself, or its speakers) or macro-level (that is, the broader setting within which the language and its speakers exist).

In March 2003, the UNESCO Expert Meeting defined nine criteria for ascertaining the vitality of a language $[8,9]$; these factors were used to provide partial assessment of the vitality of the Dumaget language among the three communities in the current study:

Factor 1: Intergenerational language transmission,

Factor 2: Absolute number of speakers,

Factor 3: Proportion of speakers within the total population,

Factor 4: Trends in existing language domains,

Factor 5: Response to new domains and media,

Factor 6: Materials for language education and literacy,

Factor 7: Language attitudes and policies,

Factor 8: Community member's attitudes toward their own language

Factor 9: Amount and quality of documentation

\section{Research Locales}

The current study focuses on the three Dumagat communities in Sitio Cabog, Barangay Matawe, Dingalan, Aurora; Sitio Pinag-anakan, Barangay Kabayunan, Angat, Bulacan; and Sitio Masla, Barangay Sablang, General Nakar, Quezon. The researchers visited Barangay Cabog on March 29-31, 2015 and on April 16-17, 2015. The first visit aimed at presenting the 
rationale of the research and being acquainted with the members of the community, though it has to be noted that LPU-COSeL has already been engaging with the community since 2010 for the PUGAHAN Project, which is a community-building initiative geared towards cultural revitalization of indigenous groups. The second visit is to conduct transect walk with the community to Kailogan, a vast land area which serves as their primary source of livelihood and their original abode before they moved to Bahay Kalinga resettlement project in Barangay Cabog. Kailogan can be reached on foot for approximately three hours by crossing rivers and climbing mountains. Some Dumagats reach some areas going to Kailogan by using habalhabal, a local term for a motorcycle designed to carry at least five passengers including the driver. The population in the area is homogenous and concentrated, but it had high contact with visitors or outsiders because of the national road accessed by buses and other vehicles.

The researchers visited the Dumagat community in Sitio Pinag-anakan in Bulacan on April 9-10, 2015. The area is one of the indigenous communities covered with the expansion of the Culturally Adaptive Basic Education and Health $(\mathrm{CABEH})$ Program, which is a collaboration among National Commission on Indigenous Peoples (NCIP), Department of Education (DepEd), and Lyceum of the Philippines University (LPU). CABEH shares mission and vision with PUGAHAN, and the two programs work together in implementing LPUCOSeL's community extension initiatives. Sitio Pinag-anakan can be reached by van from Manila to Barangay Hilltop, and by motorboat going to Angat Dam watershed areas, which serve both as the source of livelihood of the Dumagats as well as their shelter. By virtue of local government policy, only Dumagats are allowed to dwell in the watershed areas, whereas outsiders or non-Dumagats are prohibited to enter and settle in those locations. The population is homogenous but dispersed; some dwell near the school and some live in the mountains nearby. There is a very low contact with visitors and outsiders.

The researchers visited Sitio Masla in General Nakar, Quezon on April 22-23, 2015. In the visits, the researchers have participated in community building and development activities such as tree planting, English language tutorials, and community immersion. The researchers have witnessed its physical transformation from a rustic community to a place built with a school, library, water system, toilet facility, and multi-purpose halls. The population is concentrated with houses built near the school.

Research validation was conducted on January 9-10, 2016 at the Matawe Bay Farm, Sitio Cabog, Barangay Matawe, Dingalan, Aurora, where the key informants from the three ethnolinguistic groups gathered to discuss the results of the research findings.

\section{Research Instruments}

The data in this study was drawn from structured, semi-structured and unstructured interviews; focus group discussion (FGD); and participant observation. The interview questionnaire aimed to determine the research participants' demographic profiles, educational background, livelihood, ethnic identity, and the Dumaget language use in the following domains: home and family; relatives, friends, and neighbours; school or education; religion; work; business or market; religion; social and cultural community activities; and agriculture. Thirty questions were developed to correspond to these domains. The survey was conducted personally, with the aid of the community members. Data from the FGDs and participant observation was used to complement and validate the data obtained from the interviews.

\section{Research Participants}

Due to physical, spatial, and temporal limitations, comprehensive sampling was not possible to gather data for the current study. Another concern includes inapplicability of western approach of soliciting information from participants individually. With their social solidarity, Dumagats prefer to be interviewed within a group context and within the frame of 
reference of their own community. Hence, 'informed sampling' was employed[10] by identifying key informants from each locale with a view of drawing a sample that could represent their communities. Reliability was derived from selecting participants, particularly the senior members of the group, who are considered the 'keepers' of their cultural heritage, systems, and practices. Validity was assured from gathering their responses, keeping records and interpretations of them, and arriving at conclusions with their consensus and agreement through research validation.

Data Analysis

The data from the interviews was analysed using the nine criteria of language vitality, as outlined in the UNESCO Expert Meeting in March 2003 [8, 9], and was complemented by the outputs of the FGDs and participant observation that were carried out in the study.

\section{Result And Discussion}

Intergenerational Language Transmission, Absolute Number of Speakers and Proportion of Speakers within the Total Population

Based on the August 2013 LPU-DepEd-NCIP PUGAHAN Progress Report, Sitio Cabog had a total population of 440, Sitio Pinag-anakan had 108, and Sitio Masla had 241. Although the report lists the spoken languages of all the residents including the parents and their children, it was not easy to identify the exact number of Dumaget speakers. Table 1 shows the estimated number of Dumaget speakers in the three communities.

Table 1. Estimated Number of Dumaget Speakers in the Three Communities

\begin{tabular}{|l|l|l|l|l|}
\hline \multicolumn{2}{|l|}{ Dumagat Communities } & $\begin{array}{l}\text { Sitio } \\
\text { Cabog } \\
\text { (Aurora) }\end{array}$ & $\begin{array}{l}\text { Sitio Pinag- } \\
\text { anakan } \\
\text { (Bulacan) }\end{array}$ & $\begin{array}{l}\text { Sitio } \\
\text { Masla } \\
\text { (Quezon) }\end{array}$ \\
\hline $\begin{array}{l}\text { Spoken } \\
\text { Languag } \\
\text { es }\end{array}$ & Dumaget only & 25 & 42 & 14 \\
\cline { 2 - 5 } & Tagalog only & 11 & 2 & 104 \\
\cline { 2 - 5 } & $\begin{array}{l}\text { Dumaget\& } \\
\text { Tagalog }\end{array}$ & 395 & 60 & 112 \\
\cline { 2 - 5 } & $\begin{array}{l}\text { Others } \\
\text { (Dumaget\&Bik } \\
\text { ol/ Igorot/ } \\
\text { Ilokano) }\end{array}$ & 3 & - & 5 \\
\cline { 2 - 5 } & $\begin{array}{l}\text { Incapable of } \\
\text { articulation/ } \\
\text { undetermined }\end{array}$ & 6 & 4 & 6 \\
\hline Total & 440 & 108 & 241 \\
\hline
\end{tabular}

The three communities vary according to the number of Dumaget; Tagalog; Dumaget and Tagalog; and Dumaget and other language speakers, with Sitio Cabog and Sitio Pinag-anakan having more Dumaget language speakers compared to Sitio Masla in terms of ratio to the total population. Even though the UNESCO criteria state that the total number of language speakers does not necessarily mean that the language vitality is endangered, "ceteris paribus, a smaller group is likely to be under greater pressure than a larger group" [8]. This idea is supported by 
Brenzinger et al. [9]:A small population is much more vulnerable to decimation (e.g. by disease, warfare, or natural disaster) than a larger one. A small group may also merge with a neighbouring group, losing its own language and culture.

Referring to UNESCO criteria in Table 2, approximate the linguistic vitality of the Dumagat communities based on the ratio of speakers to the total population. However, it should be noted that this is only an estimate as actual language proficiency assessments have still to be conducted to ascertain the linguistic proficiency self-report from the study participants and key informants as presented in Table 1.

The UNESCO Intergenerational Language Transmission criteria suggest that the Dumaget language in Sitio Cabog (Aurora) and Sitio Pinag-anakan (Bulacan) is likely situated at Grade 5 of the language endangerment scale, while the Dumaget language in Sitio Masla (Quezon) is likely situated at Grade 3. In the UNESCO criteria, Grade 5 refers to the status of a language that is still secured because all speakers from children and up are still using it, while Grade 3 refers to a language status that is not secured because the language is no longer being learned as the mother tongue at home, and although parents may still speak their language to their children, the children do not typically respond in the language.

Table 2. Intergenerational language transmission [9]

\begin{tabular}{|l|l|l|}
\hline $\begin{array}{l}\text { Degree of } \\
\text { Endangerme } \\
\text { nt }\end{array}$ & $\begin{array}{l}\text { Grad } \\
\text { e }\end{array}$ & Speaker Population \\
\hline Safe & 5 & $\begin{array}{l}\text { The language is used by all ages, } \\
\text { from children up. }\end{array}$ \\
\hline Unsafe & 4 & $\begin{array}{l}\text { The language is used by some } \\
\text { children in all domains; it is used } \\
\text { by all children in limited } \\
\text { domains. }\end{array}$ \\
\hline $\begin{array}{l}\text { Definitely } \\
\text { endangered }\end{array}$ & 3 & $\begin{array}{l}\text { The language is used mostly by } \\
\text { the parental generation and up. }\end{array}$ \\
\hline $\begin{array}{l}\text { Severely } \\
\text { endangered }\end{array}$ & 2 & $\begin{array}{l}\text { The language is used mostly by } \\
\text { the grandparental generation and } \\
\text { up. }\end{array}$ \\
\hline $\begin{array}{l}\text { Critically } \\
\text { endangered }\end{array}$ & 1 & $\begin{array}{l}\text { The language is used mostly by } \\
\text { very few speakers of the great- } \\
\text { grandparental generation. }\end{array}$ \\
\hline Extinct & 0 & There exists no speaker. \\
\hline
\end{tabular}

Unbroken language transmission from parents to children across generations is a strong indicator of linguistic vitality of a community. In the case of Sitio Cabog and Sitio Pinaganakan, it is still evident, as all of the children are Dumaget language speakers. On the other hand, Sitio Masla's linguistic situation proves otherwise, as many children no longer speak the language. Nevertheless, the interview data suggests that all of the participants in the three communities believe in the importance of language transmission to their children and agree that the Dumaget language should be taught at home to the younger generation. The parents believe that the Dumaget language is their identity; hence, it should be learned by their children. As one parent comments:

"Bali-baliktadin man yungpagkataomo, yungwikamo'yyun pa rin ang nakatataksapagkatao mo." 
'Even if your identity is turned upside-down, your language will still be your identity marker.' (SMQ-F-1)

This is supported by another parent's sharing on how her own parents reminded her of keeping the Dumaget language with her, urging her to do the same to her own children:

"'Pag ang salitaninyoanak ay nilayoninyosasarilininyo, kayo narin ang pumutolna parang hindina kayo tunaynakatutubo."

'If you keep your own language away from you my child, it is like you cut [your lineage] as if you were no longer a true indigenous person.' (SCA-F-1)

Still following Brenzinger et al.'s perspective [9], the Dumaget language in Sitio Cabog (Aurora) and Sitio Pinag-anakan (Bulacan) is likely "stable yet threatened (5-)". "Stable yet threatened" indicates that a language is spoken in most contexts by all generations with unbroken intergenerational transmission from grandparents to parents and to children. However, multilingualism among the native language speakers and one or more dominant language(s) have started penetrating important communication spheres in the community. In this context, the dominant language refers to the language of the majority and the language of power, prestige and influence. In this case, the dominant language is Tagalog or Filipino. This linguistic situation of multilingualism among the Dumagat communities is shown in the parents' statements below:

"'Pag nasapaaralan po ang mgaanak ko, siyempre, nag-ta-Tagalog sila para maunawaansila ng kanilangmgaguro at mgakaklase, pero 'pagsila-silangnalang ang naguusap, pa-Dumagatna."

'When my children are at school, of course, they speak Tagalog so that their teachers and their classmates can understand them, but if they talk among themselves, they use Dumaget.'(SCA-F-2)

"Kumporme kung sino ang kausap... halimbawa 'pagbibilisa bayan, natural Tagalog ang gamitkasipapano ka namanmauunawaan ng tindera kung pa-Dumagat ka. Pero kung ang kasama ko ay Dumagat, sasalitangDumagat kami mag-uusap."

'It depends on who we are talking to...for example, if we buy something in town, of course we use Tagalog because how can a vendor understand you if you speak Dumaget. But if I am with a Dumagat, we converse in Dumaget. (SPB-M-1)

The following section explores the multilingual/bilingual situation of these speech communities, the position of the Dumaget language, the bilingual factor among the Dumagat speakers, and the role of the dominant language in specific communicative contexts or settings.

\section{Trends in Existing Language Domains}

Domain refers to the connection between the choice of language and the sphere and general activities of a particular society [11]. Specifically, domains are defined in terms of institutional contexts or socio-ecological co-occurrences [12]. They show the communication spheres and clusters as well as the language/s used by speakers when performing communicative acts in these settings. Domains can reveal prioritized and privileged languages that are utilized in various socio-cultural contexts. They can also show minorities and less preferred languages in realizing communicative goals in different situations.

As every particular society has different aspects and needs, the domains for language use also vary. For instance, a community that is situated in the "remotest of the remote" place will definitely have different domains than a community located in an urban area, as the life-ways and lifestyles of the people in these situations also vary. This study explores eight domains for language use among the three Dumagat communities: (1) home and family; (2) relatives, friends, and neighbours; (3) school or education; (4) work; (5) business or market; (6) religion; 
(7) social and cultural community activities; and (8) agriculture. Table 3 demonstrates the general language distribution in selected domains among the Dumagat communities.

Table 3. General Language Distribution in Selected Domains among the Dumagat

Communities

\begin{tabular}{|c|c|c|c|c|c|c|c|c|c|}
\hline \multirow[t]{2}{*}{ Domains } & \multicolumn{3}{|c|}{ Sitio Cabog (Aurora) } & \multicolumn{3}{|c|}{$\begin{array}{c}\text { Sitio Pinag-anakan } \\
\text { (Bulacan) }\end{array}$} & \multicolumn{3}{|c|}{ Sitio Masla (Quezon) } \\
\hline & $\begin{array}{c}\text { Duma } \\
\text { get }\end{array}$ & $\begin{array}{l}\text { Tagal } \\
\text { og }\end{array}$ & $\begin{array}{c}\text { Engli } \\
\text { sh }\end{array}$ & $\begin{array}{c}\text { Duma } \\
\text { get }\end{array}$ & $\begin{array}{c}\text { Tagal } \\
\text { og }\end{array}$ & $\begin{array}{c}\text { Engli } \\
\text { sh }\end{array}$ & $\begin{array}{l}\text { Duma } \\
\text { get }\end{array}$ & $\begin{array}{c}\text { Tagal } \\
\text { og }\end{array}$ & $\begin{array}{c}\text { Engli } \\
\text { sh }\end{array}$ \\
\hline $\begin{array}{l}\text { Home and } \\
\text { family }\end{array}$ & $\mathrm{x}$ & $\mathrm{x}$ & & $\mathrm{x}$ & $\mathrm{X}$ & & $\mathrm{x}$ & $\mathrm{x}$ & \\
\hline $\begin{array}{l}\text { Correspond } \\
\text { ence with } \\
\text { relatives, } \\
\text { friends, and } \\
\text { neighbours }\end{array}$ & $\mathrm{x}$ & $\mathrm{x}$ & & $\mathrm{X}$ & $\mathrm{x}$ & & $\mathrm{x}$ & $\mathrm{x}$ & \\
\hline $\begin{array}{l}\text { School or } \\
\text { education }\end{array}$ & & $\mathrm{x}$ & $\mathrm{x}$ & & $\mathrm{x}$ & $\mathrm{x}$ & $\mathrm{x}$ & $\mathrm{x}$ & $\mathrm{x}$ \\
\hline $\begin{array}{l}\text { Social and } \\
\text { cultural } \\
\text { community } \\
\text { activities }\end{array}$ & $\mathrm{x}$ & $\mathrm{x}$ & & $\mathrm{x}$ & $\mathrm{x}$ & & & $\mathrm{x}$ & \\
\hline Religion & $\mathrm{x}$ & $\mathrm{x}$ & & $\mathrm{x}$ & $\mathrm{x}$ & & & $\mathrm{x}$ & \\
\hline Work & & $\mathrm{x}$ & & & $\mathrm{x}$ & & & $\mathrm{x}$ & \\
\hline $\begin{array}{l}\text { Mass } \\
\text { Media } \\
\end{array}$ & & $\mathrm{x}$ & $\mathrm{x}$ & & $\mathrm{X}$ & $\mathrm{x}$ & & $\mathrm{x}$ & $\mathrm{x}$ \\
\hline $\begin{array}{l}\text { Business or } \\
\text { market }\end{array}$ & $\mathrm{x}$ & $\mathrm{x}$ & $\mathrm{x}$ & $\mathrm{x}$ & $\mathrm{x}$ & $\mathrm{x}$ & & $\mathrm{x}$ & $\mathrm{x}$ \\
\hline Agriculture & $\mathrm{x}$ & & & $\mathrm{x}$ & & & & $\mathrm{x}$ & \\
\hline
\end{tabular}

A general picture of the language distribution across domains in Sitio Cabog (Aurora), Sitio Pinag-anakan (Bulacan), and Sitio Masla (Quezon) is given in Table 3. This shows the bilingual status in the home and family domains among the communities, with both Dumaget and Tagalog being spoken among family members. However, it should be noted that the extent and stretch of use of these two languages vary geographically. For instance, Sitio Cabog and Sitio Pinag-anakan have reported consistent use of Dumaget in their households, although some children are starting to use Tagalog when communicating with their parents and siblings. On the other hand, only few families use Dumaget at home in Sitio Masla, as majority of the population use Tagalog, particularly those families whose parents are nonDumagats. Although the use of Dumaget in the home and family domain in Sitio Cabog and Sitio Pinag-anakan is maintained and still minimally practiced in the case of Sitio Masla, if look at all the social strata of society, Tagalog is gradually penetrating this domain. The same language behaviour holds true for community activities and contact with relatives, friends, and neighbours. The following respondent's avowal from Sitio Cabog (Aurora) illustrates this situation:

"Pag nasabahay po kami, Sir, e talagang pa-Dumagat ang amingimikan...ganunnarinsamgakapitbahaynamin. Naiibalangkapag Tagalog na ang kaharapnamin..."

'When at home, Sir, we really speak in Dumaget...as when we converse with our neighbours. It only changes when we face Tagalog speakers...' (SCA-F-2) 
In the same manner, the Dumagats in Sitio Pinag-anakan (Bulacan) also use their language at home, as stated below:

"Ditosa amin, halos lahat kami dito ay Dumagat kaya walangnagta-Tagalog samgabahay-bahay...patiyungmgaasawa ng DumagatnahindiDumagat ay natututonarinmagsalitanang pa-Dumagat ...iyonkasi ang naririnignilaaraw-araw..."

'Here in our place, almost all of us here are Dumagats, that's why nobody speaks Tagalog at home...even the husbands or wives of the Dumagats who are not Dumagats are learning how to speak Dumaget... because that is what they hear every day...'(SPB-M-1)

In contrast, the linguistic situation in Masla is slowly changing even in the home domain:

"Aaminin ko po sainyo, Sir...e talagangmadalangnalang ang nagsasalita ng paDumagatditosa amin...peromarurunongsila...perohindilangsila nag-iimikan ng paDumagat...una, dahil ang asawa ng iba ay hindiDumagat...at pangalawa parang ayawlangnilagamitin ang ganoongsalita...hindi ko alam..."

'I'll admit to you, Sir...there are really few who speak Dumaget here in our place...but they know [Dumaget]...but they just don't converse in Dumaget...first, because the wives or husbands of others are non-Dumagats... and second, it seems that they just don't want to use the language...I don't know...' (SMQ-M-1)

The first change is noticeable when looking at the school domain where both Tagalog and English are in use in all of the three communities. Being the Philippine official national language, Filipino is used as the required medium of instruction (MOI), with English being taught as a second language and used as an MOI throughout higher grades. However, with the passing of Republic Act 10523, otherwise known as the Enhanced Basic Education Act of 2013 that implements the K to 12 Basic Education Program in the Philippines, the Mother Tongue - Based Multilingual Education (MTB-MLE) was institutionalized. MTB-MLE mandates the use of students' mother tongue (L1) as MOI beginning grade 1 through grade 3 as well as the integration of local cultures into the teaching and learning process in the classroom through localization and indigenization of curriculum, as it aims to develop multilingual, multi-literate and multicultural citizens of the society. It is with this educational policy that primary schools have started to restructure their Basic Education Curriculum in order to integrate students' mother tongue in the classroom, and put premium on the importance of learning concepts through students' first language to facilitate literacy, to promote cognitive development, and to capitalize on students' prior knowledge for lesson bridging and scaffolding. This is what is now being done in Sitio Masla, which conducts mother tongue classes to its pupils from kindergarten to grade four through a community paraprofessional teacher. Still, full implementation of this program is not realized due to the emergence of some concerns such as lack of mother tongue teachers, lack of instructional materials, and lack of teacher training. While educational institutions are addressing these issues, majority of the teachers continue to use Filipino as the MOI in their classroom instruction.

Table 3 also suggests that the domain of mass media is bilingual, with Filipino and English being used as the language of radio, television, and news and broadcast. In addition, small business and official transaction on the local level take place in Tagalog, while big business, management discussions and government decisions on the higher level are communicated mostly in English. Dumaget is used only if the transaction is done by the Dumagat speakers among themselves, which usually takes within local communication contexts. This positions Dumaget as the language mainly for personal, social, and non-formal functions. 
A similar case of changing pattern in the use of Dumaget in the religious domain can be observed. Although this domain is regarded as the strongest domain in which to preserve the use of a native language, this is not the case in all of the three Dumagat communities. Both Sitio Cabog and Sitio Pinag-anakan have bilingual language status in the religious sphere, as they use both Dumaget and Tagalog in church functions, although they use Tagalog in general in order to adapt to the different linguistic orientations of the churchgoers. Dumaget is used only when all of the mass attendants are Dumagats. Although there are few religious reading materials that are translated to Dumaget from Tagalog or English by American missionaries, the Bible that they use in the church is written in Tagalog. This is partly because the mass celebrant is usually an outsider who speaks Tagalog in preaching sermons and conducting prayers.

The change in the pattern of language use in the religious domain is closely connected to the changes that take place in the Dumagat communities. Traditionally, Dumagats would use the Dumaget language in worshiping their god "Makedepat", in praying, and in performing healing rituals. This is no longer the case at present. Interview results revealed that majority of the informants have embraced Christianity. The Bible that they use in the church has been translated from English to Tagalog, and the language of preaching is Tagalog, which inevitably changes the linguistic landscape of the Dumagats' religion in general. The Tagalog's position in the religious domain of the Dumagats can be considered a dominant status, similar to the Arabic language, which is considered a superposed H (High) language among the Muslims in Malaysia and Singapore [13].

This study reveals that the life patterns among the Dumagats in these areas have slowly changed over time. The inevitable change in the social milieu of the Dumagats has gradually shifted the landscape of their practices. In terms of religion, the embrace of Christianity by most Dumagats has replaced their customs and traditions that they upheld for so long, as most of these are considered to be in conflict with the teachings of Christianity, and hence, they do not practice them anymore. In the case of work, it was observed that Dumagats do not work in the government or private offices; they have work on their own such as fishing, farming, and hunting. Some take on casual work, and some may even do not have any work at all. When they have an important transaction, they visit these offices, which are commonly run and occupied by the speakers of the dominant language. This interaction exposes them to the dominant language and may gradually contribute to a significant change in their patterns of language use. In terms of agriculture, Dumaget is still strongly used within the community, particularly in Sitio Cabog and Sitio Pinag-anakan, whereas Tagalog is more commonly used in Sitio Masla.

There is also an observable interaction of communication spheres when look into the language contact among these Dumagat communities and the other communities. In the case of Sitio Cabog in Aurora, it is geographically situated along the national highway, which exposes this group to other groups of people such as local tourists and the neighbourhoods. In short, the Dumagats in Sitio Cabog are positioned in the crossroads of cultures, and hence, may expose them easily to the other groups. In a similar situation, Sitio Masla in Quezon is also situated along the community road, even though it is considerably far from the municipality. This position exposes the Dumagats in Sitio Masla to the others groups, as it allows language contact and interaction between them and the Tagalog speakers. This continuous contact with each other will be necessary for them to communicate with each other, and so some speakers will gradually acquire (elements of) the other group's language; and while this may happen in both ways, typically the lower-status group (Dumagat) will adjust to the politically dominant one (Tagalog). If this situation persists over time, this may 
lead to what Schneider [14] refers to as emergent bilingualism, where more and more speakers of the indigenous language (in this case, Dumaget) will acquire Tagalog for practical reasons, which, in some extreme cases, may lead to complete language shift. On the other hand, Sitio Pinag-anakan in Bulacan is located in a secluded area within the Angat Dam watershed system, making it less accessible to other groups, as entry to the community is regulated by the government. The Dumagats in this area are less exposed to the other groups; the interethnic interaction only occurs when the other groups such as religious and educational institutions visit the place for some programs. Thus, the language exposure to the dominant language is reduced, and the use of the native language is maintained within the community.

Sitio Cabog in Aurora has public elementary and secondary schools, Cabog Elementary School and Cabog High School, which are located across the Dumagat community and are attended by a mixture of Dumagat and Tagalog students.Sitio Pinag-anakan in Bulacan has an elementary school, Pinag-anakan Elementary School, which contains one classroom that conducts multi-grade classes from grades 1 to 6 . Dumagat pupils who wish to continue their education in the secondary level beginning grade 7 have to go out of the area and stay in the town proper, where the municipal high school is located. Sitio Masla in Quezon has a newlybuilt elementary school in 2013, KatutubongPaaralang Jose P. Laurel (KPJPL), which was founded through the initiative of the Community Outreach and Service Learning (COSeL), Lyceum of the Philippines University's center for community extension programs and services. It has three classrooms that primarily serve Dumagat schoolchildren from kindergarten to grade 4 levels. Before the establishment of KPJPL, Dumagat children attended at Sablang Elementary School, a barangay public elementary school located around 30 to 40 minutes on foot from Sitio Masla. The MOI in all of these schools is Filipino, and English is taught as a subject, although English is also used as MOI in higher levels particularly in content areas such as Science and Mathematics. At present, it is only Sitio Masla in Quezon that offers Dumaget mother tongue classes to all of its students through a community paraprofessional teacher who is a Dumaget mother tongue speaker. The mother tongue classes are conducted in conjunction with the regular classes delivered by the teachers of the Department of Education. The classes are held every Monday morning and Friday afternoon, totalling four hours weekly for each group of learners: group 1 (composed of kindergarten, grade 1 and grade 2 pupils) and group 2 (composed of grade 3 and grade 4 pupils). Sitio Cabog in Aurora had Dumaget mother tongue classes that were also conducted by a Dumaget mother tongue speaker two years ago but the program had stopped, although recently the Dumagat community as well as the school officials are planning to re-open the program. Sitio Pinag-anakan in Bulacan did not have mother tongue classes yet, but they expressed interest in the possibility of including them in the school curriculum. The main concern among these communities is the availability of the Dumaget mother tongue speakers who will serve as Dumagat community teachers and conduct classes on a regular basis.

The use of the two national languages (Filipino and English) in the school domain as MOIs in these IP communities require students to learn to read and write and master the curriculum in both Filipino and English while at the same time acquiring these languages. This may result in low comprehension and poor intake of the subject matter particularly to those students who are not proficient in these languages. To address this concern, Gonzalez [15] suggests that a language that students understand, i.e., their mother tongue, must be used transitionally until a new MOI can be used with comprehension in the classroom.

This data shows that the patterns of language use across domains in the three Dumagat communities vary. At the institutional level, it suggests that the choice of languages for active use in situational contexts is not free, but often prescribed by the government or official bodies 
as in the case of the use of a dominant language in the educational system. This is socially conditioned diglossia[16, 17], where two languages are used in the community, with the other being utilized in the high domains and the other in the low domains. At the individual level, there is indeed a personal choice to use one of the two languages in their active use (individual bilingualism) among the Dumagats, yet this choice is always directed to the dominant language [18], which is Tagalog or Filipino in the higher domains and Dumaget in the lower domains.

The data also reveals that most of the Dumagats in Sitio Cabog and Sitio Pinag-anakan and few in Sitio Masla are stable bilinguals, who are proficient in their mother tongue and shift only to Tagalog for instrumental purposes. This stable bilingualism [12] among the Dumagat speakers enables them to switch to Dumaget or Tagalog whenever the communicative situation calls for it, without any difficulty of communicating. This suggests that the use of Tagalog among Dumaget speakers is 'incentivized', primarily motivated for purposes of educational and economic access, but not necessarily affect their ethnolinguistic identity. Table 4 demonstrates the loss of existing language use domains

\begin{tabular}{|l|l|l|}
\multicolumn{2}{|c|}{ Table 4. Loss of existing language use domains [9] } \\
$\begin{array}{l}\text { Eegree of } \\
\text { t }\end{array}$ & $\begin{array}{l}\text { Grad } \\
\text { endangermen }\end{array}$ & Domains and Functions \\
\hline Universal use & 5 & $\begin{array}{l}\text { The language is used in all } \\
\text { domains and for all functions. }\end{array}$ \\
\hline $\begin{array}{l}\text { Multilingual } \\
\text { parity }\end{array}$ & 4 & $\begin{array}{l}\text { Two or more languages may be } \\
\text { used in most social domains and } \\
\text { for most functions. }\end{array}$ \\
\hline $\begin{array}{l}\text { Dwindling } \\
\text { Domains }\end{array}$ & 3 & $\begin{array}{l}\text { The language is used in home } \\
\text { domains and for many } \\
\text { functions, but the dominant } \\
\text { language begins to penetrate } \\
\text { even home domains. }\end{array}$ \\
\hline $\begin{array}{l}\text { Limited } \\
\text { Formal } \\
\text { Domains }\end{array}$ & 2 & $\begin{array}{l}\text { The language is used in limited } \\
\text { social domains and for several } \\
\text { functions. }\end{array}$ \\
\hline $\begin{array}{l}\text { Highly limited } \\
\text { Domains }\end{array}$ & 1 & $\begin{array}{l}\text { The language is used only in } \\
\text { very restricted domains and for } \\
\text { a very few functions. }\end{array}$ \\
\hline Extinct & 0 & $\begin{array}{l}\text { The language is not used in any } \\
\text { domain or for any function. }\end{array}$ \\
\hline
\end{tabular}

Based on Table 4, it is suggested that the Dumaget language in Sitio Cabog and Sitio Pinag-anakan falls into Grade 3 of the language endangerment scale, that is, the dwindling domains, which corresponds to language use in home domains and for many functions, but the dominant language begins to penetrate even home domains. In other words, the Dumaget language is still the language being used by Dumaget speakers at home and for my functions in the community, but the dominant language, i.e., Tagalog, has begun to penetrate these spheres. On the other hand, the data suggests that the Dumaget language in Sitio Masla falls into Grade 1 category, that is, the highly limited domains, which means that Dumaget is used only in very restricted domains and for a very few functions such as the use of the language at home of few speakers. 


\section{Governmental and Institutional Language Attitudes and Policies}

Language policy is the law that is related to the construction, implementation and maintenance of language use in a particular speech community [11]. In the Philippines, the language policy is outlined in the Philippine Constitution. The 1974 and 1987 Bilingual Education policies determined the language of instruction in the Philippine educational system to be Filipino and English, despite the fact that about $80 \%$ of the population does not speak either of these languages as their first language (L1) or mother tongue. Recently, the implementation of DepEd Order No. 60, s. 2008 and DepEd Order No. 74, s. 2009 caused a significant change in the current national educational landscape. The latter recognizes that the mother tongue, when used as a language of instruction (LOI), can facilitate student learning more effectively. Even more recently,the passing of Republic Act 10523, otherwise known as the "Enhanced Basic Education Act of 2013", institutionalized the Mother Tongue-Based Multilingual Education (MTB-MLE) language policy, which is regarded as the government's banner program for education as a salient part of the implementation of the $\mathrm{K}$ to $12 \mathrm{Basic}$ Education Program (Department of Education, 2013). MTB-MLE requires instruction, teaching materials, and assessments to be in the "regional or native language of the learners" from kindergarten through grade three with a "mother tongue transition program" from grades four through six. Gradual implementation had already started with grade one students in 2012 and had been followed by grades two and three in 2013 and 2014, respectively.

Before the institutionalization of MTB-MLE, Filipino and English have been used as LOIs in the Philippine education system. These are also the languages mostly used in the public and private sectors of the government, as well as in formal business transactions. This resulted in the deterioration of functional load of the non-dominant or minority languages in the public domain. The minority languages were not taught as subjects in the school curriculum, and are used only as vernaculars in limited domains, which fail to strengthen their functional transparency, that is the degree of autonomy and control that is owned by the language in specific domains [11]. This indicates that they do not have power and prestige in the society.

However, with the integration of Philippine local and indigenous languages into the Philippine basic education curriculum through MTB-MLE, the minority languages are starting to gain support and momentum.The so-called localization or indigenization in the classroom breathes a new life in the national educational landscape and revitalizes the language situation in the Philippines.Thus, with this recent language policy, Factor 7 of the UNESCO criteria, Governmental and Institutional Language Attitudes and Policies [9], likely positions the Dumaget language in the context of threatened language vitality. Table 5 shows the governmental and institutional language attitudes and policies

Table 5. Governmental and institutional language attitudes and policies [9]

\begin{tabular}{|l|l|l|}
\hline $\begin{array}{l}\text { Degree of } \\
\text { Support }\end{array}$ & Grade & Official Attitudes toward Language \\
\hline Equal support & 5 & All languages are protected. \\
\hline $\begin{array}{l}\text { Differentiated } \\
\text { support }\end{array}$ & 4 & $\begin{array}{l}\text { Minority languages are protected primarily } \\
\text { as the language of the private domains. The } \\
\text { use of the language is prestigious. }\end{array}$ \\
\hline $\begin{array}{l}\text { Passive } \\
\text { assimilation }\end{array}$ & 3 & $\begin{array}{l}\text { No explicit policy exists for minority } \\
\text { languages; the dominant language prevails } \\
\text { in the public domain. }\end{array}$ \\
\hline
\end{tabular}




\begin{tabular}{|l|l|l|}
\hline $\begin{array}{l}\text { Active } \\
\text { assimilation }\end{array}$ & 2 & $\begin{array}{l}\text { Government encourages assimilation of the } \\
\text { dominant language. There is no protection } \\
\text { for minority languages. }\end{array}$ \\
\hline $\begin{array}{l}\text { Forced } \\
\text { assimilation }\end{array}$ & 1 & $\begin{array}{l}\text { The dominant language is the sole official } \\
\text { language, but non-dominant languages are } \\
\text { neither recognized nor protected. }\end{array}$ \\
\hline Prohibition & 0 & Minority languages are prohibited. \\
\hline
\end{tabular}

Based on Table 5, the Dumaget language is likely situated between Grade 5 and Grade 4 . In this case, it is true that all languages including the majority, minority and indigenous languages are protected by the government with the recent national educational language policy; however, at the same time, the dominant language, Filipino, still prevails in the public domain. This means that there is some degree of support from the government to the minority and indigenous languages, yet; still, there is passive assimilation that occurs because the standard Filipino language is the language of the public domain.

\section{Community Members' Attitudes towards Their Own Language}

Obiols [19] defines attitude as a "mental disposition towards something", it acts as a bridge between opinion and behaviour. Ryan and Giles [20] define language attitudes as "any affective, cognitive or behavioural index of evaluative reactions toward different language varieties or speakers." Language attitude of the members of a speech community may vary from person to person. They may see it as essential to their community and identity and promote it; they may use it without promoting it; they may be ashamed of it, and therefore, not promote it; or they may see it as a nuisance and actively avoid using it.

Interview and focus group discussion data among the three IP communities under study reveal some perspectives on community members' attitudes towards the Dumaget language. In general, all members agreed that they value their language and they wish to see it promoted for the following reasons: (1) it is their identity marker; (2) it is their legacy from their ancestors that they have to pass on to the young generation; (3) it is the bearer of their culture. These reasons are supported by the following participants' avowals:

"Eh kasi yun ang kinagisnan naming salita...di pwedengmawalasaamingsarili ang salitanamin..."

'That's the language we've born with...it's not possible to detach our language from ourselves...'(SCA-F-3)

“.......libaliktadin man, yungpagkataomo at yungwikamo'yyun pa rinnakatataksapagkataomo...."

'Whether your identity is turned upside down and reverted, your language remains etched in your identity...'(SPB-M-2)

However, even though all of the Dumagats support their language, they admit that there are also challenges that may affect in promoting and advancing their own language. These include the following: (1) social stigma associated with using the language; (2) exogamy or interethnic marriage; (3) modern technological advancements; (4) out-migration; and (4) practical reasons. One common factor cited is the social stigma that is associated in speaking the language. Speaking Dumaget in the presence of non-Dumaget speakers particularly in school usually ends up in bullying and discrimination. Several stories that have been shared regarding this issue can be traced back to the previous negative experiences of their grandparental and parental generations. It has left them deep and open wounds that would soon prevent them from using the language, particularly when they are in public places. This 
stigmatized and 'dis-incentivized' use of Dumaget even led some parents not to teach the language to their children deliberately:

"Dahil nga po sapanunukso ng mgaunat, di na kami tinuruan pang magsalita ng awing wika ng amingmgamagulang..."

'Because of the constant bullying of the non-Dumagats, our parents did not teach us how to speak our language deliberately...'(SMQ-F-3)

Interethnic marriage or exogamy is also seen as a contributory factor in the decline of use of Dumaget. The participants believe that if a Dumagat marries a non-Dumagat such as a Tagalog, this will consequently result in the changing patterns of language use at home among the parents and the children in order to accommodate one another in communication. They also concurred that if the non-Dumagat is the mother, the language of the children will likely be the language of the mother as they have longer contact hours and interaction than with the father who traditionally is the one who leaves home for work.

"Sa amin po ditosaMasla ay maraminangnakapag-asawa ng mga di tuladnamin kaya pag nag-uusapsilasabahay Tagalog na ang gamit para magkaintindihansila ..."

'Here in our place in Masla, many have already married with non-Dumagats; that's why when they converse in their homes they use Tagalog so they can understand each other...'(SMQ-M-2)

It is also believed that the advent of modern technology that is slowly affecting the lifestyles of the Dumagats is another intervening factor in the promotion of Dumaget among these communities. In particular, the communities in Sitio Cabog - Aurora and Sitio Masla Quezon already have access to electricity, and some households now own television sets, video players, and mobile phones. This exposes them to languages such as Filipino, English, and even Korean by watching TV programs and movies in DVD formats. In contrast, these technological innovations have a lesser effect in Sitio Pinag-anakan - Bulacan, which is still has no access to electricity, although some households already own some mobile phones for communication with their family members who are working and studying in the town proper. However, despite this perceived effect of modern technology towards their Dumaget language use, others maintained that it has a very little impact on them:

"Meron din, kumbaganababawasanyungpagsasalita ng pa-Dumaget, pero di namanganunkatindi ang epektokasi di namannilanakakalimutan ang salitanamin ..."

'There is (an effect), it seems that their (children) speaking in Dumaget is reduced, but the effect is not that alarming because they don't forget our language...'(SCA-F-3)

Out-migration is also seen as a factor in the promotion and maintenance of the Dumaget language. The participants believe that when any member of their family leaves their community for work or study and goes to another community where their language is not spoken, it can affect their language use, as they have to adapt to their present environment. The significant change in language proficiency, they believe, is especially apparent to young children who live in the town proper with non-Dumagats for years. Some of them, although proficient in speaking Dumaget, deliberately switch to Tagalog when speaking in their community to suggest that they have been to the city, which they believe is a good social class marker among them. However, majority still believe that in the case of the adult members of the community who have already established their proficiency in Dumaget, this is not a major concern, as they speak only Tagalog for instrumental reasons, and not as a sign of language shift.

"Yung ibangmgakabataanditonalumuwas ng lungsod para magtrabaho, pagbalik Tagalog na kung magsalita...peroalamnamannila mag-Dumagetpinipilitlangnila...para masabilangnagalingsasyudad..." 
'Some of the youth here who went to the city to work, when they come back they speak in Tagalog...but they do know how to speak Dumaget...they deliberately speak in Tagalog so others will know that they have been to the city...'(SCA-M-2)

Finally, Dumagats believe that a pervasive factor affecting the promotion and maintenance of Dumaget is the social reality of learning and using the dominant language (in this case, Tagalog) for more pragmatic reasons: educational, economic, and social access. Since Tagalog is the language of school, commerce, business, work, and government transactions, they regard using it as an advantage for their welfare. This could be the reason why some parents even encourage their children to learn Tagalog so that they can easily assimilate to the outside environment and mainstream society. The use of Tagalog is associated with social mobility, which will provide them better and bigger chances of achieving their life goals.

"Maramingmgamagulangdito Sir Tagalog natalaga ang tinuturosamgamagulangkasikailangan po sapaaralan at pag-nagtrabahona..."

"Many parents here Sir teach Tagalog to their children because it is needed in school and in their future work...'(SMQ-F-4)

Speakers' attitudes towards their own language are an essential factor in strengthening its language vitality. Based on Table 6, the three Dumagat communities under study are likely positioned between Grade 5 and Grade 4 in the UNESCO language vitality and endangerment scale, as the interview and focus group discussion data suggest that although all members of these communities support their language, some may not feel strongly about this due to the reasons outlined above. However, it should be noted that these initial findings are exploratory in nature, and hence more in-depth studies are suggested to validate these results. Furthermore, assessing language attitude is complex in nature, and can only glean from the information shared by the participants. It is also possible that their language attitude may vary across trajectory in space and time, and as linguistic reconfigurations occur to suit their life goals and everyday needs. After all, language attitude is fluid in nature and it changes dynamically with time and social changes [21].

Table 6. Community members' attitudes towards their own language [9]

\begin{tabular}{|l|l|}
\hline \multicolumn{1}{|c|}{ Grade } & Community Members' Attitudes toward Language \\
\hline 5 & All members value their language and wish to see it promoted. \\
\hline 4 & Most members support language maintenance. \\
\hline 3 & $\begin{array}{l}\text { Many members support language maintenance; others are } \\
\text { indifferent or may even support language loss. }\end{array}$ \\
\hline 2 & $\begin{array}{l}\text { Some members support language maintenance; others are } \\
\text { indifferent or may even support language loss. }\end{array}$ \\
\hline 1 & $\begin{array}{l}\text { Only a few members support language maintenance; others are } \\
\text { indifferent or may even support language loss. }\end{array}$ \\
\hline 0 & $\begin{array}{l}\text { No one cares if the language is lost; all prefer to use a dominant } \\
\text { language. }\end{array}$ \\
\hline
\end{tabular}

\section{Other Factors}

The Dumaget language in Sitio Cabog - Aurora and Sitio Pinag-anakan - Bulacan does not fulfil the criteria of Factors 6 and 9 on the UNESCO scale. Factor 6 refers to Material for Language Education and Literacy, and both of these communities are observed to have very limited materials written (some folklores and translated Biblical teachings) in Dumaget, which situates the language in the scale of Grade 1 (A practical orthography is known to the 
community, and some material is being written). It should also be noted that even though there some materials written in the language, it does not necessarily mean that they are taught to the children through classroom integration.On the other hand, the Dumaget language in Sitio Masla - Quezon is situated in the UNESCO scale at Grade 4, as there are already materials written in the language that are used in developing children's literacy through Dumaget mother tongue classes. Even so, these materials still have to be developed through language documentation and planning.

Considering Factor 9 (Amount and Quality of Documentation), the Dumaget language in Sitio Cabog - Aurora and Sitio Pinag-anakan - Bulacan is likely situated at Grade 1 (Inadequate) of the UNESCO scale, as only fragmentary texts written in the language exist, and there are no audio and video recordings of usable quality. In Sitio Masla - Quezon, the language has some existing documentations such as basic word-lists, basic communication phrasal expressions, some local stories, and a localized alphabet, which situates Dumaget at Grade 2 (Fragmentary) of the UNESCO scale.

The Dumaget language in Sitio Cabog - Aurora and Sitio Pinag-anakan - Bulacan does not fulfil Factor 5 (Response to New Domains) at it is at Grade 0 (Inactive), which means that it is not used in new domains such as school, radio, and television. The use of Dumaget usually occurs in more private domains such as the home, or in private communications such as text messaging and phone calls. The language in Sitio Masla - Quezon, however, is likely situated at Grade 1 (Minimal), as the language is used as the language of instruction in mother tongue classes at school. In general, the dominant languages, Filipino and English, are still being used in new domains. Table 7 summarizes the findings of this study. The present data suggests that the Dumagat communities in Sitio Cabog - Aurora and Sitio Pinag-anakan Bulacan have similar linguistic situations, although they may vary to some extent, while Sitio Masla (Quezon) differ from the two in certain aspects.

Table 7. Summary of the Factors on Ethnolinguistic Vitality among the Three Dumagat Communities

\begin{tabular}{|l|l|l|l|}
\hline \multirow{2}{*}{ Factors Language } & \multicolumn{3}{l|}{ Dumagat Indigenous Communities } \\
\cline { 2 - 4 } & $\begin{array}{l}\text { Sitio Cabog } \\
\text { Aurora) }\end{array}$ & $\begin{array}{l}\text { Sitio Pinag- } \\
\text { anakan (Bulacan) }\end{array}$ & $\begin{array}{l}\text { Sitio } \\
\text { (Quezon) }\end{array}$ \\
\hline $\begin{array}{l}\text { Intergenerational } \\
\text { Transmission }\end{array}$ & 5 & 3 \\
\hline Absolute Number of Speakers & $423 / 440$ & $102 / 108$ & $131 / 241$ \\
\hline $\begin{array}{l}\text { Proportion of Speakers within the } \\
\text { Total Population }\end{array}$ & 5 & 5 & 2 \\
\hline Shifts in Domains of Language Use & 3 & 3 & 1 \\
\hline $\begin{array}{l}\text { Response to New Domains and } \\
\text { Media }\end{array}$ & 0 & 0 & 1 \\
\hline $\begin{array}{l}\text { Materials for Language Education } \\
\text { and Literacy \& Institutional }\end{array}$ & 1 & 1 & 4 \\
\hline $\begin{array}{l}\text { Governmental \& Policies } \\
\text { Language Attitudes \& } \\
\text { including Official Status \& Use }\end{array}$ & 5 & 5 & 5 \\
\hline $\begin{array}{l}\text { Community Members Attitudes } \\
\text { toward Their Own Language }\end{array}$ & 5 & 5 & 2 \\
\hline $\begin{array}{l}\text { Amount \& Quality of } \\
\text { Documentation }\end{array}$ & 1 & 1 & \\
\hline
\end{tabular}




\section{Conclusion}

This exploratory study presents a sociolinguistic perspective on the ethnolinguistic vitality of the three Dumagat indigenous communities in Sitio Cabog, Barangay Matawe, Dingalan, Aurora; Sitio Pinag-anakan, Barangay Kabayunan, Angat, Bulacan; and Sitio Masla, Barangay Sablang, General Naka, Quezon Province. Using the Language Vitality and Endangerment Scale of UNESCO [9] in analysing the data drawn from the interview, focus group discussions and participant observation, the findings reveal that the Dumaget language in these communities are under threat and are likely to deteriorate because the nine factors proposed by UNESCO have not been fulfilled. However, while this may be the general case, the degree of threat and the extent of deterioration may vary from community to community.

With the present data, the functional load and functional transparency of the Dumaget language vary among the three communities. Both the Dumagat communities in Sitio Cabog Aurora and Sitio Pinag-anakan - Bulacan still have strong intergenerational language transmission and language use in the home domain is still intact. These are still strong signs of vitality as language endangerment experts regard these factors as the most important in the UNESCO language vitality assessment scale (author here). The governmental support through Mother Tongue-Based Multilingual Education (MTB-MLE) may also help in promoting the language. However, the low ratings in other factors may gradually affect the language maintenance, as the functional load in the public domains is generally occupied by the dominant languages, i.e., Filipino and English. Sitio Pinag-anakan's geographical position may help lessen the effects of these factors across time, but it is still not a guarantee since the globalization forces and urbanization efforts are in place and gaining momentum. Sitio Cabog faces a stronger threat as it is susceptible to language contact with Tagalog due to its geographical location, and hence, multilingualism is inevitable, which can soon lead to the decline in the use of Dumaget.

The Dumagat community in Sitio Masla - Quezon faces the strongest threat of language deterioration as it does not fulfil satisfactorily the nine criteria set forth by UNESCO. With very limited functional load even at the home domain, weak intergenerational language transmission, and mixed attitudes of community members towards the language, it is likely to decline fastest among the three communities.

Because of the growing awareness among the members of these IP communities about the advantages of learning Tagalog for their economic and educational access, it is seen that the trend in learning more of the majority language and less of their indigenous language may increase as years go by. It may even extend to learning another majority language such as English as they struggle to exist and survive in an increasingly challenging, marginalizing and demanding knowledge-based economy. And as they strive for social and economic inclusion, education and literacy will serve as their key for their rights and self-determination [22,23].

As multilingualism and plurilingualism come with the advent of modern technology that penetrates into the different domains of the society, as well as the seemingly borderless and seamless flow of information, goods and services across various contexts, the modern Dumagat has to adapt with these changes and adopt feasible mechanisms in order to keep up and to continuously build contacts at all levels: regional, community, individual [24]. These changes seem to come in two-fold: while these communities may be facing language endangerment and cultural loss, their political empowerment is also coming underway. It is then our hope that the concerted efforts of those in "power" work in to contribute to the revitalization, reinvigoration and preservation [25] of the Dumagat communities' language and culture, as help them become "self-determined rather than outwardly imposed" [23]. 


\section{Acknowledgments}

The authors would like to acknowledge the unconditional support from the College of Arts and Sciences, Lyceum of the Philippines University.

\section{References}

[1] Lewis, M., Simons, G., and Fennig, C. eds. 2013. Ethnologue: Languages of the World, 17th ed. Dallas, TX: SIL International.

[2] Headland, T. 2010. Why the Philippine negrito languages are endangered. Endangered Languages of Austronesia, M. Florey, ed. Oxford University Press. 110-118.

[3] Reid, L. 2013. Who are the Philippine Negritos?: Evidence from language. Human Biology.85, 1, $1-32$.

[4] Reid, L. 1989. Arta, another Philippine negrito language. Oceanic Linguist. 28, 47-74.

[5] Giles, H., Bourhis, R. and Taylor, D. 1977. Towards a theory of language in ethnic group relations. In H. Giles (Ed.), Language, Ethnicity and Intergroup Relations.London: Academic Press. 307-348.

[6] Edwards, J. 1992. Sociopolitical aspects of language maintenance and loss: Towards a typology of minority language situations. Maintenance and loss of minority languages, Fase, J. and Kroon, ed. Philadelpha: J Benjamins, 37-54.

[7] Grenoble, L. and Whaley, L. 1998. Toward a typology of language endangerment. Endangered languages, ed. Grenoble and Whaley. Cambridge: Cambridge University Press.22-54.

[8] Lewis, M. P. 2006. SIL Electronic Working Papers SILEWP 2006-002. [Internet]. [cited 16 March 2020]. Available from: http://www.sil.org/silewp/abstract.asp?fef=2006-002

[9] Brenzinger, M., Y. Akira, A, Noriko, K. Dimitri, M. Anahit, D. Arienne, G. Colette, K. Michael, M. Osahito; S. Osamu, S. Rieks, and Z. Ofelia, 2003, Language vitality and endangerment: Paris: UNESCO Ad Hoc Expert Group Meeting on Endangered Languages. [Internet]. [cited 16 March 2020]. Available from: http://unesdoc.unesco.org/images/0018/001836/183699E.pdf

[10] Tiessen, C. 2003. Positive orientation towards the vernacular among the Talysh of Sumgayit. MA Thesis: University of North Dakota.

[11] Mohamed, N. and Hashim, N. H. 2012. Language Vitality of the Sihan Community in Sarawak, Malaysia. Kemanusiaan. 19, 1, 59-86.

[12] Fishman, J. 1972. The relationship between micro- and macro-sociolinguistics in the study of who speaks what language to whom and when. Sociolinguistics. eds. J. B. Pride and Janet Holmes. Harmondsworth: Penguin Books Ltd., 15-32.

[13] Noriah, M., Hashim, H. and Lah, Y.C. 2009. Factors that influence the sustainability usage of three endangered indigenous languages in Malaysia. The International Journal of the Humanities. 7, 6, 169-193.

[14] Schneider, E. 2007. Post-colonial English: Varieties around the World, Cambridge: Cambridge University Press.

[15] Gonzalez, A. 1996. Using Two/Three Languages in Philippine Classrooms: Implications for Policies, Strategies and Practices. Journal of Multilingual and Multicultural Development. 17:2-4, 210-219.

[16] Ferguson, C. 1959. Diglossia. Word. 15, 325-340.

[17] Fishman, J. 1967. Bilingualism with and without diglossia; diglossia with and without bilingualism. Journal of Social Issues. 23, 29-38.

[18] Dirven, R., and Pütz, M. 1993. Intercultural communication. Language Teaching. 26, 03, 144.

[19] Obiols, M.S. 2002. The Matched Guise Technique: A Critical Approcimation to a Classic Test for Formal Measurement of Language Attitudes. [Internet]. [cited 16 March 2020]. Available from: http://www.cultura.gencat.net/llengcat.noves

[20] Ryan, E.B. and Giles, H. 1982. Attitudes towards Language Variation. Edward Arnold: London.

[21] Mee-ling, L. 2009. 'I love Cantonese but I want English' - A Qualitative Account of Hong Kong Students' Language Attitudes. The Asia-Pacific Education Researcher. 18, 1, 79-92. 
[22] López L.E., and Sichra I. 2008. Intercultural Bilingual Education Among Indigenous Peoples in Latin America. In: Hornberger N.H. (eds) Encyclopedia of Language and Education. Springer, Boston, MA

[23] Hussain, A., Abdullah, A., Husni, H., Mkpojiogu, E.O.C. (2016). Interaction design principles for edutainment systems: Enhancing the communication skills of children with autism spectrum disorders.RevistaTecnica de la Facultad de Ingenieria Universidad del Zulia, 39 (8), pp. 45-50.

[24] Stenzel, K. 2006. Multilingualism in the Northwest Amazon, Revisited. [Internet]. The Archive of the Indigenous Languages of Latin America [cited 16 March 2020]. Available from: http://www.ailla.utexas.org/site/cilla2/Stenzel_CILLA2_vaupes.pdf

[25] Zuckermann, G. and Walsh, M. 2011. Stop, Revive, Survive: Lessons from theHebrew Revival Applicable to the Reclamation, Maintenance and Empowerment ofAboriginal Languages and Cultures. Australian Journal of Linguistics. 31, 1, 111-127. 